Cities of Ladies 
THE MIDDLE AGES SERIES

Ruth Mazo Karras, Series Editor

Edward Peters, Founding Editor

A complete list of books in the series is available from the publisher. 


\section{Cities of Ladies}

\section{Beguine Communities in the Medieval Low Countries,$$
\text { 1200-1565 }
$$

WA LTER SIMONS

$\overline{\text { PENN }}$

University of Pennsylvania Press

Philadelphia 
Copyright $(92001$ University of Pennsylvania Press

All rights reserved

Printed in the United States of America on acid-free paper

10987655432

Published by

University of Pennsylvania Press

Philadelphia, Pennsylvania 19104-4011

Library of Congress Cataloging-in-Publication Data

Simons, Walter.

Cities of ladies: Beguine communities in the medieval low countries, 1200-1565 / Walter Simons. p. cm. (The Middle Ages series)

Includes bibliographical references and index.

ISBN: o-8122-3604-1 (cloth : alk. paper). - ISBN: o-8122-1853-1 (pbk. : alk. paper)

I. Beguines-Benelux countries-History. II. Monasticism and religious orders for womenBenelux countries-History-Middle Ages, 600-1500. III. Benelux countries-Church history. IV. Church history-Middle Ages, 600-1500.

$\begin{array}{llll}B X_{4272 . S 56} & 2001 \quad 274.92 / 05 / 082 & 21 & 2012345117\end{array}$ 